\title{
Article \\ The Effect of Monetary Policy and Private Investment on Green Finance: Evidence from Hungary
}

\author{
Goshu Desalegn ${ }^{1, *(\mathbb{D}}$, Maria Fekete-Farkas ${ }^{2} \mathbb{D}$ and Anita Tangl ${ }^{3}$ \\ 1 Doctoral School of Economics and Regional Sciences, Hungarian University of Agriculture and Life Sciences, \\ Páter Károly u. 1, 2100 Gödöllő, Hungary \\ 2 Institute of Agricultural and Food Economics, Hungarian University of Agriculture and Life Sciences, \\ Páter Károly u. 1, 2100 Gödöllő, Hungary; farkasne.fekete.maria@uni-mate.hu \\ 3 Institute of Rural Development and Sustainable Economy, Szent István Campus, Hungarian University of \\ Agriculture and Life Sciences, Páter Károly u. 1, 2100 Gödöllő, Hungary; tangl@vajna.hu \\ * Correspondence: deresa.goshu.desalegn@phd.uni-mate.hu
}

Citation: Desalegn, Goshu, Maria Fekete-Farkas, and Anita Tangl. 2022. The Effect of Monetary Policy and Private Investment on Green Finance: Evidence from Hungary. Journal of Risk and Financial Management 15 117. https://doi.org/10.3390/ jrfm15030117

Academic Editor: Ming-Lang Tseng

Received: 18 February 2022

Accepted: 1 March 2022

Published: 3 March 2022

Publisher's Note: MDPI stays neutral with regard to jurisdictional claims in published maps and institutional affiliations.

Copyright: (C) 2022 by the authors. Licensee MDPI, Basel, Switzerland. This article is an open access article distributed under the terms and conditions of the Creative Commons Attribution (CC BY) license (https:// creativecommons.org/licenses/by/ $4.0 /)$

\begin{abstract}
The objective of this study was to examine the effect of monetary policy and private investment on green finance in the case of Hungary. The study used an explanatory research design and a quantitative research approach. Quarterly secondary time series data over 8 years (2013-2020) were utilized. More specifically, the study used Johnson co-integration test and vector error correction model to investigate the long and short-run relationship among variables. The study's findings imply that monetary policy, as measured by interest rates and the broad money supply, has a mixed effect on the level of green financing. Interest rates, in particular, have a negative and significant relationship with green finance in both the long and short run. However, a broad money supply has a positive but insignificant relationship with green finance in the long run. Private investment has a positive and significant relationship with green financing in both the long and short run. The study also used inward and outward foreign direct investment, and greenhouse gas as a control variable of the study. The study finding implies that inward foreign direct investment has a positive and significant relationship with green financing in both the long and short run. On the other hand, outward foreign direct investment and the level of greenhouse gas have a negative and significant relationship with green finance in both the long and short run. The study also discovered that over time series, disturbance in domestic private investment was the most determinant factor in forecast error variance of green financing. In addition, the result of document analysis shows that the majority of Hungarian credit institutions are dealing with their corporate strategy rather than their sustainability strategy. Hence, progressive approaches are needed from the credit institution to frame their strategy under the concept of sustainable development goals. The finding of this study will contribute to the existing literature on the study area, provide suggestions on green finance and green monetary policy approaches, provide implications on key stakeholders of green financing, as well as the experience of different economies. The study advises central banks, credit institutions, and regulatory authorities to consider both neoliberal and reformist approaches of green finance and green monetary policies in aid to increase green investment.
\end{abstract}

Keywords: green finance; monetary policy; private investment

JEL Classification: B23; E52

\section{Introduction}

Green finance is the way to increase the level of financial flows from all sectors (banking, micro-credit, insurance, public, private, and not-for-profit organizations) to sustainable development priorities (Lindenberg 2014). As the investment in the green sector has been growing at a fast pace in recent years, the demand for green finance is also increasing at the fastest pace (Taghizadeh-Hesary and Yoshino 2019). However, a 
large financial gap still exists between the current amount of green investment and what would be required to de-carbonize the economy (Campiglio 2016). The latest accounting of climate finance shows that there is still a huge amount of financial gap to de-carbonize the economy (Ziolo et al. 2017), and calls all concerned stakeholders to find ways to leverage additional resources to preserve healthy ecosystems on land and in the oceans (Lv et al. 2021). From this aspect, the green finance gap was found to be very wide and no certainty exists regarding how to fill it (Debrah et al. 2022). Moreover, the finding of most study shows emerging disappointments in green investment because of the shortage of green finance (Chang et al. 2021). Scholars have many arguments on factors currently preventing economic resources from flowing in larger amounts to green investments.

The first argument is the miserable macroeconomic environment. After the financial crisis of 2007, the global economic system in general and high-income countries (Zenghelis 2012), in particular, has been suffering a period of lethargic economic activity that has led to recession and high unemployment (Sutherland 2020). The consequence creates low investment levels in the economy and prevents a lack of confidence among economic agents (Campiglio 2016).

The second and critical factor is the nature of green investments regarding risk and returns trade-off. In this case, the perception of risks related to technology evolution and market development is the concern of green investors (Criscuolo and Menon 2015). Besides, many governments are currently backing off from providing support to the sector because of the stress posed by the economic crisis (Francisco and Paulo 2015). As the result, a large amount of green finance gap is observed. In light of the expected risk-return trade-off, returns on green investments should be very high to attract investors (Polzin et al. 2021). There is, however, little attention given to compensating green investors in enhancing green finance for better green investment (Debrah et al. 2022).

Regarding the issue, some studies were conducted from different perspectives on green financing and provide helpful recommendations in a way to fill the green finance gap (Naqvi et al. 2021; Debrah et al. 2022; Sutherland 2020; Lyeonov et al. 2019; and Olmos et al. 2012). Still, there is a huge financial gap for making a green investment. These may raise concerns about the role of various stakeholders such as international financial institutions, monetary policies, institutional investors, and private, and public investors in promoting green finance. To be specific, there are arguments that monetary policy has received little attention in global discussions about green finance, and most central banks are criticized for not starting their role in assisting society in meeting its environmental goals, and letting alone the potential implications of environmental degradation for their mandates (Monnin and Barkawi 2015). Furthermore, the study conducted by Batrancea et al. (2020), suggests that the majority of monetary policy in application for the financial sectors are the main reason for green financing gap. The study conducted by Debrah et al. (2022) supports this idea and suggests that the role of monetary policy is deemed high in encouraging green finance, which would aid in green investment. On the other hand, (Markham 2022) argues that the using of monetary policy to finance the financial gaps could create the long term economic uncertainty, and affects the financial markets as well as the price of certain safe assets. Hence, it is critical to shed light on this blind spot. As central banks transfer billions of dollars into the global economy on a monthly basis, understanding their actions on green economy in general and green finance in particular could be beneficial. Furthermore, it would provide a thorough examination of policy alternatives and their environmental consequences.

In the context of Hungary, the country is lagging in terms of the Sustainable Development Goals (SDGs), particularly in terms of environmental goals. Hungary ranks 19th in Europe overall in terms of SDGs and faces significant challenges in the areas of affordable and clean energy (Goal 7), climate protection (Goal 13), and terrestrial ecosystem preservation (Goal 14). Further, it is believed that these will hurt the country's long-term economic performance and financial system (Jeklin 2016). Furthermore, the country's financial system has only recently begun to incorporate environmental sustainability concerns into its 
operations, so there is currently little data on "green finance". Hence, the urgent need for economic transformation, in which the financial system must devote fewer resources to environmentally harmful activities (MNB 2019). To expand the green financial segment, it is also necessary to examine credit institutions' strategies, for which the MNB conducted a voluntary questionnaire survey among credit institutions in April 2019.

According to this survey, few of the responding banks have an issued sustainability strategy, but many report a corporate strategy. The survey results also show that there are no green savings products. Only one credit institution offers a deposit product in which the depositor may, among other things, instruct the deposit-collecting bank to grant lower interest rates to borrowing customers in its lending activities for green investment. In this case, therefore, it is the bank, rather than the depositor, that sacrifices some of its interests at the expense of its profit (MNB 2019).

To that end, it is observed that the majority of Hungary's credit institution sector sees the most business potential in financing renewable energy production, with (35 percent) of credit institutions expecting an increase in these projects, as well as the achievement of sustainability goals (16 percent), energy efficiency projects ( 13 percent), and the transition to climate neutrality (10 percent). As a result, the Hungarian central bank is currently encouraging the banking sector to increase the level of green lending, as well as suggesting that the banking sector provide clients with loans with lower interest rates or fees, and track energy efficiency characteristics for new loans. However, greater mobilization of private investments and adjustment on financial regulations are required by the central bank to finance the mitigation of the effects of climate change and environmental degradation, as well as economic adaptation (MNB 2019). From there, it is possible to understand that a large number of green funds will be required to finance energy efficiency projects. However, it remains to be seen how and where these green funds will be provided.

In this regard, no scientific studies have been conducted to investigate the role of monetary policy and private investment in enhancing green finance regarding a specific study area. As a result of these empirical gaps, the researchers are motivated to present a tremendous opportunity as a suggestion for the tasks that each stakeholder in green finance enhancement is required to fulfill and to provide a policy suggestion on an approach to green funds. Hence, the purpose of this study is to investigate how monetary policies and private investment respond to green finance. In doing so, the study used interest rate and broad money supply as proxies for monetary policy, used by (Monnin and Barkawi 2015), as well as a domestic private investment as proxies for private investment. On the other hand, greenhouse gas emissions, inward foreign direct investment, and outward foreign direct investment are used as a control variable of the study.

The main contribution of this study is to analyze the long-term and short-term effects of monetary policy, and private investment on green finance. The study will contribute to empirical gaps observed in the study area, and provide implications on the relationship between variables used in the study. Furthermore, the literature on the study provides an implication on key stakeholders of green financing and the experience of different economies, as well as the approaches of green finance and green monetary policy.

The subsequent part of the study explores the study's literature review. Section 3 discusses the study's research methodology, Section 4 discusses the study's findings, and Section 5 presents the study's conclusion and policy recommendations.

\section{Literature Review}

Following the adoption of the Paris Agreement, green finance began to gain traction. It is the financing mechanism that involves a variety of financial institutions, both public and private, as well as various asset categories such as green bonds, green loans, green funds, and so on, all of which are responsible for financing environmentally friendly investments (Sutherland 2020). Recent studies show that climate investment requires finance ranging from USD 1.6 to 3.8 trillion per year for the global energy system's supply-side until 2050, and in developing countries alone, the financing gap for achieving the SDGs is estimated to 
be USD 2.5 trillion per year (Monasterolo 2020). In addition, it is believed that the domestic credit from banks is not sufficient to achieve this green financing gap as the level of green finance demand and development is increasing from time to time (Taghizadeh-Hesary and Yoshino 2019).

To close the financing gap, capital mobilization for green investments is highly required, however, it has been limited due to several macro and microeconomic challenges, such as maturity mismatches between long-term green investments and investors' relatively short-term time horizons (Berrou et al. 2019), lack of analytical tools and expertise in identifying and assessing green project risks (Francisco and Paulo 2015), lack of coordination between financial and environmental policy approaches (Monasterolo 2020), and policy uncertainty and short-termism in the financial system (Lyeonov et al. 2019).

The financing tools such as green bonds and climate bonds were introduced for funding environmentally beneficial initiatives (Tolliver et al. 2020). As many academic writers have pointed out (Akomea-Frimpong et al. 2021; Chang et al. 2021; Pyka and Nocon 2021; Aller et al. 2018; Baloch et al. 2018; Bovari et al. 2020; Lamperti et al. 2021), however, the financial gap on green investment is still huge in amount.

Addressing the green finance gap requires coordination between governments and other financial institutions for the implementation of new financing models. All stakeholders in the capital markets, in both private and public sectors, need to be encouraged for green investment participation and the development of infrastructure-related financial assets (Debrah et al. 2022).

The study conducted by (Khudyakova and Urumov 2021), suggests that central banks and other financial regulators must play an active role in developing a legislative framework for green finance. To do so, progressive approaches are demanded against financial and monetary regimes that allow for environmental solutions based on global solidarity and democratic economic governance for green financing (Criscuolo and Menon 2015). Emerging markets and developing countries, in particular, have to put in place a slew of policies to mobilize funds for long-term development and integrate green financing into their financial system (Barbier 2020). As such, the financial industry has also played an important role in increasing green financing (Giramkar 2018). To support this, the study conducted by (Mumtaz and Smith 2019) suggests that the developing countries shall follow the foot of developed countries in a bid to fill the green finance gap. The study further suggests that green finance could create links between technological development, innovation, and the greening of the economy to explore untapped opportunities for economic growth. However, the processes associated with the financial system must be solved through regulatory authorities like central banks.

Most empirical studies imply that the role of central banks and regulatory authorities has a significant effect on green financing, and investment decisions (Lamperti et al. 2021). More specifically, the study conducted by (Monnin and Barkawi 2015) implies that monetary policy has received little attention in global discussions, similar to central banks in assisting society in meeting its environmental goals. On the other hand, private investors are also the largest actor in enhancing green finance (Liu 2018). However, the private investment contribution is not as much expected compared to other investment alternatives.

Several studies justify the reason behind the low contribution of private investment in comparison to others (Cárdenas Rodríguez et al. 2015; Ruiz et al. 2016; TaghizadehHesary and Yoshino 2019), and highlights that the nature of green investments in terms of risk and return trade-off is one of the reasons mentioned, among others (Ruiz et al. 2016). According to (Focardi and Fabozzi 2020; Akomea-Frimpong et al. 2021; Bovari et al. 2020), to increase the level of private green investment, creating coordination between financial, and environmental regulations are suggested. To do so, the role of government authorities and monetary policies are found important (Berrou et al. 2019). In the following section of the study, the study will discuss how monetary policy measurements and private investments are associated with green finance. 


\subsection{Monetary Policy and Green Finance}

The lending rate is used as the first proxy to measure monetary policies in this study. The rate charged by lenders on the amount lent for a specific period is known as the lending rate (Pyka and Nocon 2021). The lending interest rate cap has an impact on the ability of green finance to grow. The green finance incentive will be determined by the loaning scale if the green finance lending interest rate is lower than the conventional lending interest rate. According to the study conducted by (Chen et al. 2019), the lower lending interest rate on green loans boosts the level of green finance and green innovation. Furthermore, the study conducted by (Campiglio 2016) shows that lending strategies that take interest rates into account will increase credit generation in low-carbon sectors. This policy is more feasible in emerging markets, where the central banking system typically allows for greater public control over credit distribution as well as a broader range of monetary policy instruments. Furthermore, the study conducted by (Si et al. 2021), shows that green loans have more explaining power in scenarios with weak green preferences than in scenarios with strong green preferences, indicating that the level of lending rate has explaining power of green loans in scenarios with weak green preferences. Hence based on the result of the previously conducted study, this study expects a negative relationship between lending interest rate and green finance.

Hypothesis 1 (H1). The lending rate has a negative and significant effect on the level of green finance.

The broad money supply was the second proxy variable used to assess the monetary policy. The volume of broad money in the economy is an indicator of financial sector transactions with other money holders such as households, non-financial corporations, and the government (Dikau and Volz 2021). Previously developed models on broad money supply highlight two main reasons for holding money. Initially, it was assumed that they are used to guide the analysis of monetary developments, as a means of quantifying the contribution of various economic determinants to money growth. Second, it establishes a normative framework for establishing whether the economy's money stock is consistent with price stability and interpreting deviations from that norm (Chen et al. 2021). The result of financial transactions for both green and non-green investments in the economy is predicted to improve when the wide money supply in the market is increased. At the same time, money supply may have an impact on asset values and, as a result, on agents overall wealth position (Chadha et al. 2010). As a result, assessing monetary changes is inextricably related to assessing the long-term viability of wealth and asset price trends. In this study, broad money (M3), which includes currency, deposits with an agreed maturity of up to two years, deposits redeemable at notice of up to three months and repurchase agreements, money market fund shares/units, and debt securities up to two years, are used as the percentage of gross domestic product (GDP). Hence the study expects a positive relationship between broad money supply and green finance.

Hypothesis 2 (H2). Broad money supply has a positive and significant effect on green finance.

\subsection{Private Investment and Green Finance}

Private investment is most commonly used as a catch-all term for the investment made by an individual or a small group of individuals rather than a large organization (Taghizadeh-Hesary and Yoshino 2019). As more people gain access to large amounts of liquid capital, private investment has emerged as a way to take a higher risk with potentially much larger gains than traditional investing. The research conducted on the study area strongly suggests that meeting green finance demands with only financial sector financing is impossible (Zenghelis 2012). As a result, it is argued that private investors pave the way in financing green investment (Cárdenas Rodríguez et al. 2015). 
Regarding domestic private investment, there are numerous questions in the current environmental issue that attempt to investigate how both domestic private and public interventions can aid green investments. The research conducted by (Polzin et al. 2021) on the relationship between public interventions and green investment suggests that policies have a positive impact on private finance. The study also implies that public intervention can influence private investments to provide direct financings, such as R\&D funds, grants, subsidies, and loan and risk guarantees. Furthermore, the study conducted by (Olmos et al. 2012) suggests that the financial sacrifice incurred on green finance by private investment should be composted by public policies by taking tax breaks and trade discounts into account. Hence, based on the assumptions of previously conducted studies, the following hypothesis is developed to investigate the relationship between private investments and green finance.

\subsection{Control Variables}

Foreign direct investments (FDIs) are long-term investments that take place outside of the investor's economic or physical boundaries. The recipient country of FDI is equipped with both capital and technology flows that will aid in its development. In this case, when one country seeks to invest in another, the benefit sought must be greater than the risks encountered (Hamid et al. 2020). However, as a result of the emergence of environmental pollution and greenhouse gas emissions, many countries are enacting environmental regulations, especially targeting foreign direct investments (Ayamba et al. 2019). It is believed that enacting environmental regulations could result in the transfer of polluting industries from countries with stricter environmental regulations to those with less stringent environmental regulations (Djellouli et al. 2022), and differences in environmental regulations are assumed to have a significant impact on foreign direct investment flows and natural resources (Caetano et al. 2022).

Furthermore, according to (Deng et al. 2021), most firms invest overseas to avoid the institutional constraints of their home countries. In this case, it is possible to see how the host country's institutional constraints and environmental regulations have a significant impact on the decisions and motivations of both foreign and domestic investors. In this regard, policymakers and academicians are becoming more interested in green finance, as green finance has the potential to mobilize market mechanisms to assist in resolving natural resource and environmental externalities (Chen et al. 2020). However, more stringent environmental regulations stifle funding for green investments. According to the findings of a study conducted by (Dudic et al. 2018) strict environmental control raises firm production costs, which increases multinational corporations' willingness to invest in places with laxer environmental regulations than in places with stricter environmental regulations, allowing these firms to shift their investments from domestic to foreign.

Inward foreign direct investment is also responsible for many externalities, which provide benefits to the home country that do not generate income for the host country (Imoughele and Ismaila 2014). With this in mind, the question of whether inward or outward foreign direct investment improves green financing by taking environmental regulations into account arises. According to the findings of the study conducted by (Peng et al. 2008), institutional barriers in the host country have a direct impact on outward foreign direct investment and affect the development and execution of foreign direct investment hence a decrease in green finance generated from this sector.

Additionally, the study confirmed the existence of the high impact of institutional characteristics of the home country, such as judicial independence, on multinational corporations' investment decisions. Furthermore, (Witt and Lewin 2007) found that outward foreign direct investment is influenced by the host country's institutional constraints, which lead to their evasion and escapism through this type of investment. Similarly, (Boisot and Meyer 2008) discovered that for tax-haven countries, outward foreign direct investment may become a strategic exit from the domestic market rather than a strategic entry into for- 
eign markets. It is also believed that government effectiveness, the legal system, corruption, taxation policies are among the limitations that make firms to cross-border investment.

Finally, the study used greenhouse gases as a control variable of the study. Greenhouse gases are the sum of seven gases that have a direct impact on climate change: carbon dioxide $(\mathrm{CO} 2)$, methane (CH4), nitrous oxide (N2O), chlorofluorocarbons (CFCs), hydrofluorocarbons (HFCs), perfluorocarbons (PFCs), sulfur hexafluoride (SF6), and nitrogen trifluoride (NF3). The figures are in $\mathrm{CO} 2$ equivalents and refer to gross direct emissions from human activities. Examining the relationship between green finance and greenhouse gas emissions can thus provide information on how far green investment financing reduces carbon emissions. Based on the result of previously conducted studies and theoretical assumptions, the study hypothesized the following relationship between the variables.

Hypothesis 3 (H3). Inward foreign direct investment has a positive and significant effect on green finance.

Hypothesis 4 (H4). Outward foreign direct investment has a negative and significant effect on green finance.

Hypothesis 5 (H5). Domestic investment has a negative and significant effect on green finance.

Hypothesis 6 (H6). Greenhouse gases have a positive and significant effect on green finance.

\subsection{Approaches to Green Finance and Green Monetary Policies}

There have been various approaches to green finance and green monetary policy. The neoliberal approach is the most known. This approach is used to describe a set of policies that rely heavily on market forces, tend to limit public sector participation, and favor the private sector.

Green finance and monetary policy initiatives that are neoliberal can be justified by mainstream neoclassical economics, particularly environmental economics. This approach has three types of neoliberalism strategies: laissez-faire neoliberal green finance, standard neoliberal green finance, and market-making neoliberal green finance.

According to laissez-faire neoliberal green finance and green monetary policy, the actions of financial investors are a critical component in addressing environmental issues. This approach is criticized by other neoliberal approaches because it implies that the values of financial assets are determined not by demand for them, but by rational expectations about future returns. These could be evidenced by several scholars as the majority of private investors are not willing to make a green investment because of future risk and returns trade-off (Criscuolo and Menon 2015).

Standard Neoliberal Green Finance is the second type of Neoliberal Green Finance. This approach is based on a less radical and more common neoclassical viewpoint, which holds that environmental problems are caused by externalities that can be socialized through taxes and/or subsidies. This approach provides a successful policy option represented in green finance by proposing (indirect) subsidization of private green investment. These subsidies can take the form of public guarantees, such as those used to de-risk Private-Public Partnerships (PPPs) or green credit guarantee schemes (GCGSs).

The third type of neoliberal green finance is market-making neoliberal green finance. Market-making neoliberal green finance is the umbrella term for policies and laws that establish and support markets. Such policies include not only property rights legislation, but also standards such as "green" taxonomy. Measures to improve standardization are expected to boost transparency and make the design and operation of markets and financial products easier. Markets are likely to work more effectively towards environmental goals as a result of this.

The other approach is reformist forms of green finance and green monetary policy. This approach believes that the state should play a more active role in accomplishing environmental goals. The reformists are against neoliberal green finance and criticize the 
market for environmental issues. They are classified as tax-based reformist, and command and control policies.

Green finance and green monetary policy that is reformist tends to shift expenses to private corporations and the financial sector while benefiting lower-income people. The tax-based reformist suggests taxes for environmentally harmful activities and uses financial resources for public environmental policies such as the provision of green infrastructure. It further discourages private sector investment and encourages the public provision of environmental goods. On the other hand, the command policy reformist believes that the most important factor in introducing environmentally friendly economic activities is not the financial sector, but the rules that govern real economic activities. These policies are followed and supported by the private sector.

The third approach is known as the progressive forms of green finance and monetary policy. This approach is highly supported by those advocators of capitalist production and environmental sustainability. Two essential pillars support progressive green finance and green monetary policy. To begin, strict environmental regulations are regarded as essential, much like in reformist perspectives. However, the norms should ensure that everyone has a fair share of environmental resources and that there is no overuse of environmental resources on a global scale.

To summarize, both the reformist and progressive approaches ignore the overuse of environmental resources for profit maximization and believe that private corporations and the financial sector should bear environmental costs and charge them to benefit lowerincome people. The neoliberal approach, on the other hand, favors the private sector.

The current study suggests both neoliberal and reformist approaches to green finance and green monetary policies. If current financial regulations do not favor private green investors, the willingness to make green investments will be hampered due to the riskreturn trade-off. As a result, not favoring green investors may widen the financing gap, putting the achievement of sustainable development goals in jeopardy, as well as the de-carbonization of the economy.

Encouraging private green investors is deemed critical for bridging the current and future green financing gap. To attract green investors, regulatory bodies must provide different incentive mechanisms (tax breaks) as opposed to a tax-based reformist approach. From the reformist point of view, the command-and-control policy is more appropriate to encourage and increase private investment participation. If the economic regulations are supported by environmental regulations and set some common command economic activities, it will reduce the overuse of the environment. As a result, this study recommends that all regulatory bodies develop a new approach that would tolerate both reformist and neoliberal approaches to green finance and green monetary policy.

Finally, the empirical analysis shows that some empirical studies on green finance have been conducted from various perspectives but are not specific to the current study under investigation. As a result of sustainable development goals and the need to decarbonize the economy, the issue of green finance is receiving increased attention. Hence this study lies in the importance of monetary policy and private investment as a mechanism for solving specific economic/finance problems in times of financial gap. Additionally, it is helpful to identify approaches to green finance and green monetary policy. Scholars and researchers who want to use the findings as a foundation for current and future research on the subject may benefit from this study.

\subsection{Conceptual Framework}

The following conceptual framework is developed to represent the study. In doing so, the study used green finance as the dependent variable. The first independent variable used in the study was a monetary policy which is measured by long-term interest rate and broad money supply. Private investment was used as the second independent variable and measured by domestic private investment. The level of greenhouse gas, outward, and 
inward foreign direct investment are used as a control variable of the study. The following Figure 1 of the study shows the conceptual framework of the study.

Independent and control variable
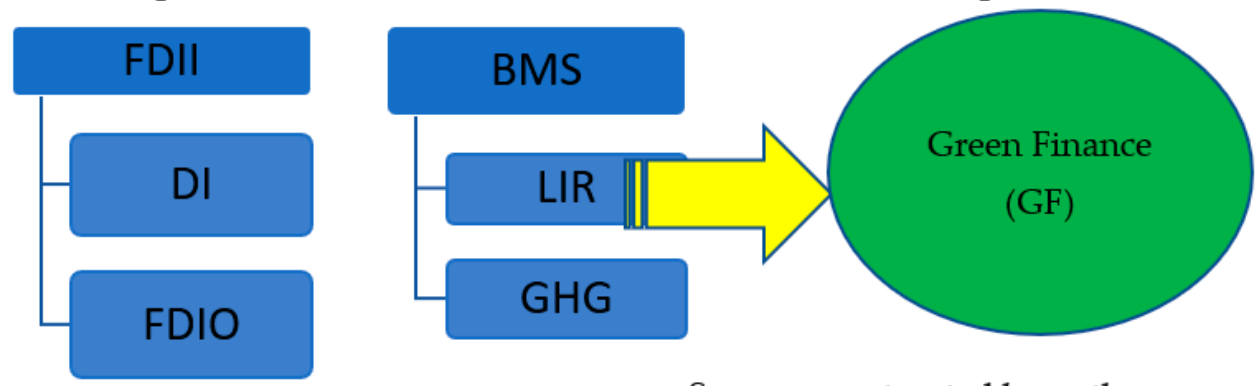

Source: constructed by authors

Figure 1. Conceptual framework of the study. NB: BMS = Broad money supply. LIR = lending interest rate. FDIO = outward foreign direct investment. FDII = inward foreign direct investment. $\mathrm{DI}=$ domestic investment. $\mathrm{GHG}=$ greenhouse gas .

\section{Material Used}

To investigate the impact of monetary policy, and private investment on green financing, the researchers employed an explanatory research design and a quantitative research approach. Secondary data were gathered from various websites, publications, and yearly reports for this study. The data on dependent and independent variables are conducted from the Magyar Bank and the OECD database.

The study's target population was all data related to dependent and independent variables. The study utilized over 8 years (2013-2020) of secondary quarter data. The sampling frame is based on quarterly time series data for both dependent and independent variables. This period was chosen based on available data for green finance. The country's financial system has only recently begun to incorporate environmental sustainability concerns into its operations, so there is currently little data on green finance (2013-2020). The study used purposive sampling techniques for data utilization and variable selection.

\subsection{Model Specification}

The following general model was developed to achieve the study purpose. The dependent variable used in this study was green finance. The independent variable was interest rate, broad money supply, inward foreign direct investment, outward foreign direct investment, domestic investment. Further, greenhouse gas was used as a control variable.

The regression equation was as follows:

$$
\text { GF : } f(I R, B M S, F D I I, F D I O, D I, G H G)
$$

$G F=$ green finance (measured as outstanding loan on green finance, and natural logarithm is applied for this variable);

$I R=$ interest rate (measured by lending interest rate);

$B M S$ = broad money supply (measured as a percentage of GDP);

$F D I I=$ inward foreign direct investment (measured as a percentage of GDP);

$F D I O=$ outward foreign direct investment (measured as a percentage of GDP);

$D I=$ domestic investment (natural logarithm is applied for this variable);

$G H G$ = greenhouse gas (measured as the sum of seven gases that have direct effects on climate change and measured as tones per capita).

The Equation (1) can be rewritten in the following econometric model with its functional forms. 
After the econometric equation is derived, the next step is a selection of the model that shall be adopted to estimate the coefficients on the variables. Before the decision was made on the model selection the study was interested to test the stationarity level of variables. In doing so, the study used the unit root test as a measurement and was performed through the Augmented Dickey-Fuller (ADF) test. The following Table 1 of the study shows the result of the stationarity test performed through the Augmented Dickey-Fuller (ADF) test.

Table 1. The result of the stationarity test.

\begin{tabular}{cccc}
\hline \multicolumn{2}{c}{ At Level } & At 1st Difference & \multirow{2}{*}{ Decision } \\
\cline { 1 - 3 } Variables & INTERCEPT & INTERCEPT & \\
\hline GF & 0.1211 & $0.0000^{* * *}$ & Stationary at I (1) \\
IR & 0.2336 & $0.0001^{* * *}$ & Stationary at I (1) \\
BMS & 0.8430 & $0.0731^{*}$ & Stationary at I (1) \\
FDIO & 0.1735 & $0.0000^{* * *}$ & Stationary at I (1) \\
FDII & 0.1333 & $0.0000^{* * *}$ & Stationary at I (1) \\
DI & 0.3236 & $0.0800^{*}$ & Stationary at I (1) \\
GHG & 0.5147 & $0.0001^{* * *}$ & Stationary at I (1)
\end{tabular}

Source: the researcher's computation using E-view 12 software. Note: * shows significance level at 10 percent, **** shows significance level at 1 percent.

The result of the stationarity test performed through Augmented Dickey-Fuller (ADF) implies that all variables are stationary after first differencing. The result further implies that all variables are the integration of I (1). According (Ahking 2002), if all variables are integrated of I (1), the long relationship of the variables can be investigated through Johansen co-integration test.

If the result of the Johansen co-integration test confirms the existence of the longrun relationship between variables, the study can estimate both the short and long-run estimation of the variables through the VAR model (Ahking 2002). At the same time, the study also performed determination of lag length criteria using final prediction error (FPE), Akaike information criterion (AIC), and Schwarz information criterion (SIC). The following Tables 2 and 3 of the study shows the result of the Johansen co-integration test and lag length criteria.

Table 2. The result of lag length criteria.

\begin{tabular}{ccccccc}
\hline \multicolumn{7}{c}{ VAR Lag Order Selection Criteria } \\
\hline \multicolumn{7}{c}{ Endogenous Variables: GF IR FDIO FDII DI GHG BMS } \\
\hline Lag & LogL & LR & FPE & AIC & SC & HQ \\
0 & -179.3775 & NA & 0.000587 & 12.42517 & 12.75212 & 12.52976 \\
1 & 15.36583 & $285.6236^{*}$ & $3.88 \times 10^{-8 *}$ & $2.708944^{*}$ & $5.324513^{*}$ & $3.545687^{*}$ \\
2 & 53.66411 & 38.29827 & $1.44 \times 10^{-7}$ & 3.422393 & 8.326584 & 4.991286
\end{tabular}

* Indicates lag order selected by the criterion. LR: sequential modified LR test statistic (each test at 5\% level); FPE: Final prediction error; AIC: Akaike information criterion; SC: Schwarz information criterion; HQ: Hannan-Quinn information criterion.

Before testing the long-run relationship between variables, the study use to identify the number of the lag length required to run the model. In doing so, final prediction error (FPE), Akaike information criterion (AIC), and Schwarz information criterion (SIC) were used to perform the result, and the result confirms that the study needs one period lag to capture the relationship between variables.

As it can be seen from the above Table 3, the result of the Johansen co-integration test performed through the Max-eigenvalue test, and Trace test indicates 1 co-integrating equation(s) at the 0.05 level. The result further confirms that there is a long-run relationship between variables. Hence the null hypothesis of no long relationship is rejected at a 
5 percent significance level. Hence the study used a vector error correction model to estimate the short-run coefficients of the variables.

Table 3. Johansen co-integration test.

\begin{tabular}{ccccc}
\hline Hypothesize & & Trace & $\mathbf{0 . 0 5}$ & \\
\hline No. of CE(s) & Eigenvalue & Statistic & Critical Value & Prob. ${ }^{* *}$ \\
\hline None * & 0.818517 & 141.1495 & 125.6154 & 0.0040 \\
At most 1 & 0.635405 & 89.95165 & 95.75366 & 0.1173 \\
At most 2 & 0.569713 & 59.68262 & 69.81889 & 0.2452 \\
At most 3 & 0.411794 & 34.38353 & 47.85613 & 0.4810 \\
At most 4 & 0.324961 & 18.46319 & 29.79707 & 0.5320 \\
At most 5 & 0.189849 & 6.673625 & 15.49471 & 0.6159 \\
At most 6 & 0.011849 & 0.357595 & 3.841465 & 0.5498 \\
\hline Hypothesized & & Max-Eigen & $\mathbf{0 . 0 5}$ & \\
\hline No. of CE(s) & Eigenvalue & Statistic & Critical Value & Prob. ${ }^{* *}$ \\
\hline None * & 0.818517 & 51.19780 & 46.23142 & 0.0136 \\
At most 1 & 0.635405 & 30.26903 & 40.07757 & 0.4064 \\
At most 2 & 0.569713 & 25.29909 & 33.87687 & 0.3651 \\
At most 3 & 0.411794 & 15.92034 & 27.58434 & 0.6725 \\
At most 4 & 0.324961 & 11.78956 & 21.13162 & 0.5686 \\
At most 5 & 0.189849 & 6.316030 & 14.26460 & 0.5730 \\
At most 6 & 0.011849 & 0.357595 & 3.841465 & 0.5498 \\
\hline
\end{tabular}

Trace test indicates 1 cointegrating eqn(s) at the 0.05 level. Max-eigenvalue test indicates 1 cointegrating eqn(s) at the 0.05 level. * denotes rejection of the hypothesis at the 0.05 level; ${ }^{* *}$ MacKinnon-Haug-Michelis (1999) $p$-values.

\subsection{Model Used}

After the result of the stationarity test conforms all variables are integrated of order one I (1), Vector Autoregressive Analysis was employed in this study (VAR). The VAR model can be used to assess long-run linear relationships among variables using the cointegration test (Demetrescu et al. 2022). When dealing with non-stationary series with a unit root, first differencing looks to be the best way to ensure that the series remains weakly stationary (Toraman and Başarir 2014). In this case, if the variables are co-integrated at first differencing the VAR model is appropriate to estimate the long and short-run relationship of the variables.

The general representation of a VAR model in the following form is given by describing the interrelationships among the $n$ variables in the model of Johnson co-integration test (Ahking 2002).

$$
Y t=\Omega+\sum_{i=1}^{n} \beta i(X) t-i+\varepsilon t
$$

where $Y t$ is an $(n \times 1)$ vector containing variable interest green finance, $\Omega$ is $(n \times 1)$ vector of constants, $\beta i$ is $(n \times n)$ matrix of coefficients, $(X) t-i$ is $(n \times n)$ the lags of endogenous variables (including GF, IR, FDII, FDIO, DI, GHG). Further, $\varepsilon t$ is the error term. The above general equation can be used in the study as the following equation.

$$
\begin{aligned}
G F t= & \beta 0+\sum_{i=1}^{h} B 1 i(I R) t-i+\sum_{i=1}^{h} B 2 i(B M S) t-i+\sum_{i=1}^{h} B 3 i(F D I I) t-i+\sum_{i=1}^{h} \\
& B 4 i(F D I O) t-i+\sum_{i=1}^{h} B 5 i(D I) t-i+\sum_{i=1}^{h} B 6 i(G H G) t-i++\varepsilon t
\end{aligned}
$$

Following the acceptance of the general model, the study conducts several tests to see if the model was clear and useful for policy suggestions. The model's feasibility was subsequently confirmed using tests for heteroscedasticity, serial correlation, and stability test. Please refer to Appendix A for further information. 


\section{Discussion}

Before moving to the econometric discussion, it is better to provide some insight into the raw data of both dependent and independent variables regarding trends over time. As a result, the following section of the study discusses descriptive statistics of each variable's using the mean, median, minimum, maximum, and standard deviation calculated using the E-views 12 software package. The descriptive statics results for each variable were displayed in the following study's Table 4.

Table 4. The result of descriptive statistics.

\begin{tabular}{ccccccc}
\hline & GF & IR & BMS & FDGI & FDGO & DI \\
\hline Mean & 3555.008 & 3.502396 & 59.81832 & 0.722253 & -0.932164 & 7.255763 \\
Median & 3238.266 & 3.213334 & 58.65200 & 2.615126 & 1.896924 & 10.97715 \\
Maximum & 8296.384 & 6.300000 & 76.96020 & 7.702407 & 4.894218 & 23.65980 \\
Minimum & 1005.177 & 1.923333 & 56.48750 & -13.01849 & -14.14979 & -17.86887 \\
Std. Dev. & 1407.901 & 1.252512 & 4.459771 & 5.819159 & 5.636956 & 10.96004 \\
Observations & 32 & 32 & 32 & 32 & 32 & 32 \\
\hline Source: E-views 12. & & & & & &
\end{tabular}

According to the descriptive statistics shown in Table 4, the study was carried out with 32 quarterly observation data for all variables. Green finance was used as the dependent variable in the study, and it was measured as the number of outstanding loans on green investment from all financial sectors. According to data from (MNB 2019), the average outstanding loan balance on green finance during the study period was HUF 3555 billion.

During the study period, the maximum loan outstanding on green finance was HUF 8296 billion, with a minimum of HUF 1005 billion. The first explanatory variable that was used as a proxy for monetary policy was the lending interest rate. According to the row data, the average lending interest rate during the study period (2013-2020) was 3.5 percent, with maximum and minimum lending rates of 6.3 and 1.92 percent, respectively. Each lending interest rate observation used in the study deviates from the mean value by 1.25 percent. Customers were charged an average of 3.5 percent interest for the bankapproved long-term loan.

The broad money supply was the second explanatory variable used as a proxy for monetary policy. According to the row data used in the study, the mean value of broad money supply as a percentage of GDP during the study period was 59.8 percent, with a maximum of 79.6 and a minimum of 56.48. In aspects of private investment, the proxy variable used in this study was a domestic private investment. The study's Table 4 above shows the mean, minimum, maximum, and standard deviation of each variable. At the same time, the outcome of the control variables inward and outward foreign direct investment, and greenhouse gas can be observed.

\section{Econometric Analysis}

The result of the Johnson co-integration test indicates the presence of a long-run relationship among variables, as stated in the methodology section. As a result, the VECM is well suited to predicting monetary policy and private investment responses to green finance. Furthermore, the VECM demonstrates how variables interact in the short run and adjust to establish long-term equilibrium (Ahking 2002). The following (Table 5) of the study shows the long-term relationship between the variables.

Table 5. Long-run estimation of the model.

\begin{tabular}{ccccccc}
\hline \multicolumn{7}{c}{ Normalized Co-Integrating Coefficients (Standard Error in Parentheses) } \\
\hline GF & IR & FDIO & FDII & DI & GHG & BMS \\
\hline \multirow{2}{*}{1.000000} & 0.092966 & 0.198798 & -0.167059 & -0.006792 & 0.008136 & -15.45592 \\
& $(0.01475)$ & $(0.00980)$ & $(0.00826)$ & $(0.00090)$ & $(0.00812)$ & $(0.73457)$ \\
\hline
\end{tabular}




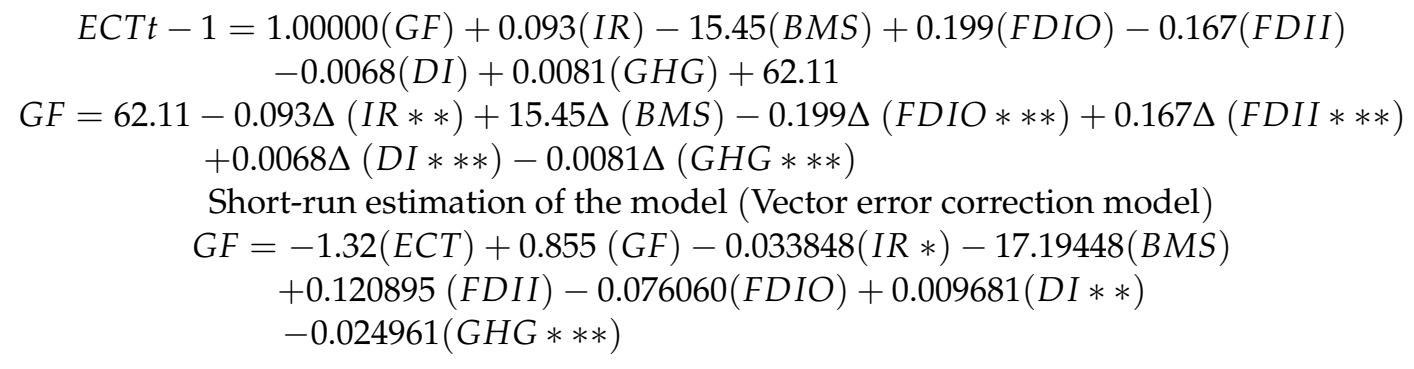

Source: E-view 12 software. Note: * shows significance level at 10 percent, ${ }^{* *}$ shows significance level at 5 percent, ${ }^{* * *}$ shows significance level at 1 percent.

The error correction term (ECM), which indicates the rate of adjustment, has a value of -1.32 . It is considered correctly signed (Behera et al. 2021). This means that the short-run disequilibrium, as well as inconsistencies, are being adjusted and corrected in the long run at a rate of 132 percent. The negative sign confirms the existence of long-term equilibrium.

From the above long and short-run estimation, we can understand that the variable interest rate has a negative and significant relationship with green financing. The result of the Johnson Normalized coefficient suggests that a 1 percent increase in lending interest rates leads green finance to drop by 0.093 percent, and is statistically significant. The explanation for the negative association between the variables is that as interest rates rise, borrowers must pay more interest, which reduces the investor's profit and reduces the willingness to make green investments. In this context, low-interest rates may present a welcome opportunity to increase long-term investments in a green economy. The lower the interest rate, the more attractive projects are that require investments today to save money and reap future benefits. Renewable energy projects are an example of this. They require the highest capital to start the project, however, low running cost thereof. Hence the monetary policy can affect this investment decision by influencing interest rates. The finding of this variable is consistent with the study established by (Pyka and Nocon 2021).

The variable broad money supply, on the other hand, has a positive but insignificant relationship with green finance in the long run and a negative and insignificant relationship in the short run. The finding of this variable is insignificant in both estimations, however, the long run sign of the relationship lends credit to the study conducted by (Markham 2022) which states that a large amount increase in money supply will increase in parallel the demand for money from economic agents and results in economic uncertainty in the long run and the lower opportunity cost of holding high cash balances in such a low-interest-rate environment.

Domestic private investment is found to have a positive and significant impact on the level of green financing in both the short and long run. The long-run regression output implies that a 1 percent increase in domestic investment causes a 0.006 percent increase in green finance, which is statistically significant at a 1 percent significance level. The positive relationship implies that increased private investment in green investment helps the government and financial institutions to finance green investments. As a result, an increase in the private level fills the green financing gap that could occur in the market. The result of this study is consistent with the study established by (Cárdenas Rodríguez et al. 2015).

Green financing has a negative relationship with outward foreign direct investment in both the long and short run. However, short-term estimates show the insignificant effect of outward foreign direct investment on green finance. According to the long-run regression results, a 1 percent increase in outward foreign direct investment results in a 0.199 decrease in green financing, and is statistically significant at the 1 percent significance level in the long run. The negative association between the variables implies that as outward foreign direct investment keeps going from the host country, green finance tends to decrease, and this could affect overall the level of green finance in the long run than the short run. The finding of this study lends credit to the study conducted by (Djellouli et al. 2022), which suggests that enacting environmental regulations could result in the transfer of polluting industries from 
countries with stricter environmental regulations to those with less stringent environmental regulations and causes outward foreign direct investment to rise. The finding of the variable is consistent with the study established by (Chen et al. 2020).

Inward foreign direct investment, on the other hand, has a positive relationship with green financing in both short- and long-run estimation. However, short-term estimates show the insignificant effect of inward foreign direct investment on green finance. According to the long-run regression result, a 1 percent increase in inward foreign investment produces a 0.167 percent rise in green financing and is statistically significant at the 1 percent significance level. The implication behind the positive relationship implies as a more inward foreign direct investment generates more assets to the host country resulting in finance advantage over green investment.

Finally, the findings revealed a negative and significant relationship between greenhouse gas emissions and green finance in both the short and long run. The study's long-run estimation indicates that a unit increase in green financing reduces greenhouse gas levels and is statistically significant at the 1 percent significance level. As a result, an increase in green finance raises the level of green investment and reduces greenhouse gas emissions.

The variance decomposition results (Table 6) show that the variable green finance can be forecasted completely by disturbance from itself (100 percent). The results show that the lagged value of the dependent variable can explain the total variation in the dependent variable. As shown in the table above, disturbances in a domestic private investment account for 3.3 percent of the forecast error variance of green financing. This finding implies that, of the available determinants of green finance, domestic private investment accounts for the lion's share of increasing the level of green financing. Moreover, outward foreign direct investment (1.47 percent), interest rate (1.42 percent), greenhouse gas (1.24), broad money supply ( 0.37 percent $)$, and inward foreign direct investment ( 0.055 percent) plays a significant role in forecasting disturbance of dependent variable, respectively. Over the 10 years, period disturbances in domestic private investment were found the most determinant factor to forecast error variance of green financing.

Table 6. Variance decomposition of green finance.

\begin{tabular}{|c|c|c|c|c|c|c|c|c|}
\hline Period & S.E. & GF & IR & FDIO & FDII & DI & GHG & BMS \\
\hline 1 & 0.124026 & 100.0000 & 0.000000 & 0.000000 & 0.000000 & 0.000000 & 0.000000 & 0.000000 \\
\hline 2 & 0.168880 & 92.14001 & 1.424186 & 1.473529 & 0.055862 & 3.293546 & 1.241139 & 0.371723 \\
\hline 3 & 0.199502 & 86.13370 & 1.517870 & 1.634901 & 2.239852 & 6.114054 & 0.931378 & 1.428245 \\
\hline 4 & 0.229616 & 82.25391 & 1.288712 & 1.773822 & 4.795255 & 7.825163 & 0.726077 & 1.337055 \\
\hline 5 & 0.260408 & 79.34868 & 1.013072 & 2.161900 & 6.335398 & 9.322064 & 0.648033 & 1.170852 \\
\hline 6 & 0.289132 & 76.55475 & 0.896904 & 2.557912 & 7.593455 & 10.73740 & 0.580741 & 1.078846 \\
\hline 7 & 0.316097 & 74.21842 & 0.880298 & 2.891961 & 8.663644 & 11.84736 & 0.512527 & 0.985790 \\
\hline 8 & 0.341783 & 72.42583 & 0.868615 & 3.210467 & 9.437234 & 12.70433 & 0.460811 & 0.892707 \\
\hline 9 & 0.366125 & 70.98023 & 0.874156 & 3.508055 & 9.997421 & 13.40328 & 0.420594 & 0.816266 \\
\hline 10 & 0.389136 & 69.78686 & 0.898993 & 3.768975 & 10.43264 & 13.97204 & 0.386501 & 0.753983 \\
\hline
\end{tabular}

Source: E-views 10.

\section{Conclusions}

In recent years, green finance has grown in popularity as a method of dealing with environmental issues. However, whether green financing is effective in addressing current global environmental issues remains to be seen, as the green investment gap was discovered to be very large, with no certainty as to how it can be fixed. According to previous studies (Baloch et al. 2018; Baniya et al. 2021; Cárdenas Rodríguez et al. 2015; Criscuolo and Menon 2015), the current environmental and financial regulations gaps are the main significant reason for the green finance gap.

The purpose of this study was to investigate the role of monetary policy and private investment in enhancing green finance. Different approaches to green finance and green monetary policies were reviewed. Reformist and progressive green finance approaches hold private investments and financial institutions accountable for environmental causes. 
As the result, they believe that private corporations and the financial sector should bear environmental costs inform of charge. The neoliberal approach, on the other hand, favors the private sector.

The result of the regression analysis of the study implies that monetary policy, as measured by interest rates and the broad money supply, has a mixed effect on the level of green financing. Interest rates, in particular, have a negative and significant relationship with green finance in both the long- and short-run (Pyka and Nocon 2021). However, a broad money supply has a positive but insignificant relationship with green finance in the long run.

Private investment, as measured by domestic private investment, has a positive effect on the level of green financing in both long- and short-run estimation (Cárdenas Rodríguez et al. 2015). The study also discovered that over 10 years, disturbance in domestic private investment were the most determinant factor in forecast error variance of green financing. Furthermore, the study's finding implies that inward foreign direct investment has a positive and significant relationship with green financing in both the long and short run.

On the other hand, outward foreign direct investment, and greenhouse gases have a negative and significant effect on green finance (Chen et al. 2020).

In addition, the result of document analysis shows that the majority of Hungarian credit institutions are dealing with corporate strategy than sustainability strategy. Hence progressive approaches are needed from the credit institution to frame their strategy under the concept of sustainable development goals. Finally, the study advises central banks, credit institutions, and regulatory authorities to consider both neoliberal and reformist approaches of green finance and green monetary policies in aid to increase green investment. More specifically, the study suggests that when determining the level of green lending, as well as to encourage all private investors, the level of interest rate be considered, and a disruption in domestic private investment was the most determinant factor in forecast error variance of green financing. Furthermore, it could be more strongly suggested that the financial sacrifice made by private investment in green finance be composted by public policies that take into account tax breaks, interest rates, and trade discounts.

Author Contributions: Conceptualization, G.D. and M.F.-F.; investigation, resources, and data curation, A.T.; methodology G.D.; analysis, and software, G.D.; original draft preparation, validation, G.D., M.F.-F., and A.T.; supervision, M.F.-F. And A.T.; project administration, and funding acquisition, A.T. and M.F.-F. All authors have read and agreed to the published version of the manuscript.

Funding: The APC was funded by the Hungarian University of Agriculture and Life Science, Doctoral school of Economic and regional sciences.

Institutional Review Board Statement: Not applicable.

Informed Consent Statement: Not applicable.

Data Availability Statement: The data can be available from request goshudasalegn@gmail.com.

Conflicts of Interest: The authors declare no conflict of interest.

Appendix A

\begin{tabular}{ccccccc}
\hline \multicolumn{7}{c}{ VEC Residual Serial Correlation LM Tests } \\
\hline At lag h & & & & & \\
Lag & LRE * stat $^{*}$ & $\mathrm{df}$ & Prob. & Rao F-stat & $\mathrm{df}$ & Prob. \\
1 & 29.23482 & 49 & 0.9888 & 0.488947 & $(49,45.0)$ & 0.9924 \\
2 & 30.95198 & 49 & 0.9795 & 0.524671 & $(49,45.0)$ & 0.9858 \\
\hline
\end{tabular}

Note: the sign of * shows statically significance of the Probability of LM test at $95 \%$ confidence level, which shows existence of serial correlation. As a result, in this study there is no evidence for existence of serial correlation $(p>0.05)$. 


\begin{tabular}{ccc}
\hline \multicolumn{3}{c}{ VEC Residual Heteroskedasticity Tests (Levels and Squares) } \\
\hline & Joint test: & \\
Chi-sq & df & Prob. \\
459.2573 & 448 & 0.3463 \\
\hline
\end{tabular}

\section{References}

Ahking, Francis. 2002. Model mis-specification and Johansen's co-integration analysis: An application to the US money demand. Journal of Macroeconomics 24: 51-66. [CrossRef]

Akomea-Frimpong, Iaasc, David Adeabah, Deborah Ofosu, and Emmanuel Tenakwah Jr. 2021. A review of studies on green finance of banks, research gaps and future directions. Journal of Sustainable Finance E Investment 11: 1-24. [CrossRef]

Aller, Carlos, Maria Jesus Herrerias, and Javier Ordonez. 2018. The Effect of Financial Development on Energy Intensity in China. Energy Journal 39: 25-38. [CrossRef]

Ayamba, Emmanuel Caesar, Chen Haibo, Abdual-Aziz Ibn Musah, Appiah Ruth, and Andrew Osei-Agyemang. 2019. An empirical model on the impact of foreign direct investment on China's environmental pollution: Analysis based on simultaneous equations. Environmental Science and Pollution Research 26: 16239-48. [CrossRef] [PubMed]

Baloch, Muhammad Saad, Abubakr Saeed, Ishtiaq Ahmed, Judit Olah, Jozsef Popp, and Domician Mate. 2018. Role of Domestic Financial Reforms and Internationalization of Non-Financial Transnational Firms: Evidence from the Chinese Market. Sustainability 10: 3847. [CrossRef]

Baniya, Bishal, Damien Giurco, and Scott Kelly. 2021. Changing policy paradigms: How are the climate change mitigation-oriented policies evolving in Nepal and Bangladesh? Environmental Science and Policy 124: 423-32. [CrossRef]

Barbier, Edward B. 2020. Is green rural transformation possible in developing countries? In World Development. Oxford: PergamonElsevier Science Ltd., vol. 131.

Batrancea, Ioan, Larissa Batrancea, Malar Maran Rathnaswamy, Horia Tulai, Gheorghe Fatacean, and Mircea-Iosif Rus. 2020. Greening the financial system in USA, Canada and Brazil: A panel data analysis. Mathematics 8: 2217. [CrossRef]

Behera, Smruti Ranjan, Tapas Mishra, Devi Prasad Dash, and Lingaraj Mallick. 2021. What drives energy consumption in brics countries? Evidence from ARDL bounds testing approach. In Singapore Economic Review. Singapore: World Scientific Publ. Co., Pte Ltd. [CrossRef]

Berrou, Romain, Nicola Ciampoli, and Vladimiro Marini. 2019. Defining Green Finance: Existing Standards and Main Challenges. In Rise of Green Finance in Europe: Opportunities and Challenges for Issuers, Investors and Marketplaces. Edited by Migliorelli M and Dessertine P. London: Palgrave, pp. 31-51. [CrossRef]

Boisot, Max, and Marshall W. Meyer. 2008. Which way through the open door? Reflections on the internationalization of Chinese firms. Management and Organization Review 4: 349-65. [CrossRef]

Bovari, Emmanuel, Gael Giraud, and Florent McIsaac. 2020. Financial impacts of climate change mitigation policies and their macroeconomic implications: A stock-flow consistent approach. Climate Policy 20: 179-98. [CrossRef]

Caetano, Rafaela Vital, Antonio Cardoso Marques, Tiago Lopes Afonso, and Isabel Vieira. 2022. A sectoral analysis of the role of Foreign Direct Investment in pollution and energy transition in OECD countries. Journal of Environmental Management 302: 114018. [CrossRef]

Campiglio, Emanuele. 2016. Beyond carbon pricing: The role of banking and monetary policy in financing the transition to a low-carbon economy. Ecological Economics 121: 220-30. [CrossRef]

Cárdenas Rodríguez, Miguel, Ivan Haščič, Nick Johnstone, Jérôme Silva, and Antoine Ferey. 2015. Renewable Energy Policies and Private Sector Investment: Evidence from Financial Microdata. Environmental and Resource Economics 62: 163-88. [CrossRef]

Chadha, Jagjit, Luisa Corrado, and Qi Sun. 2010. Money and liquidity effects: Separating demand from supply. Journal of Economic Dynamics and Control 34: 1732-47. [CrossRef]

Chang, Youngho, Qiang Ji, and Dayong Zhang. 2021. Green finance and energy policy: Obstacles, opportunities, and options. Energy Policy 157: 112497. [CrossRef]

Chen, Qiuping, Bo Ning, Yue Pan, and Jinli Xiao. 2020. Green finance and outward foreign direct investment: Evidence from a quasinatural experiment of green insurance in China (Sep, 10.1007/s10490-020-09750-w, 2021). In Asia Pacific Journal of Management. New York: Springer. [CrossRef]

Chen, Shuanglian, Zhehao Huang, Benjamin M. Drakeford, and Pierre Failler. 2019. Lending Interest Rate, Loaning Scale, and Government Subsidy Scale in Green Innovation. Energies 12: 4431. [CrossRef]

Chen, Yao, Nuno Palma, and Felix Ward. 2021. Reconstruction of the Spanish money supply, 1492-1810. Explorations in Economic History 81: 101401. [CrossRef]

Criscuolo, Chiara, and Carlo Menon. 2015. Environmental policies and risk finance in the green sector: Cross-country evidence. Energy Policy 83: 38-56. [CrossRef]

Debrah, Caleb, Albert Ping Chuen Chan, and Amos Darko. 2022. Green finance gap in green buildings: A scoping review and future research needs. Building and Environment 207: 108443. [CrossRef]

Demetrescu, Matei, Vladimir Kusin, and Nazarii Salish. 2022. Testing for no cointegration in vector autoregressions with estimated degree of fractional integration. Economic Modelling 108: 105694. [CrossRef] 
Deng, Ziliang, Tingting Li, and Peter W. Liesch. 2021. Performance shortfalls and outward foreign direct investment by MNE subsidiaries: Evidence from China. International Business Review 31: 101952. [CrossRef]

Dikau, Simon, and Ulrich Volz. 2021. Central bank mandates, sustainability objectives and the promotion of green finance. Ecological Economics 184: 107022. [CrossRef]

Djellouli, Nassima, Latifa Abdelli, Mohamed Elheddad, Rizwan Ahmed, and Haider Mahmood. 2022. The effects of non-renewable energy, renewable energy, economic growth, and foreign direct investment on the sustainability of African countries. Renewable Energy 183: 676-86. [CrossRef]

Dudic, Branislav, Zdenka Dudic, Jan Smolen, and Vladimir Mirkovic. 2018. Support for foreign direct investment inflows in Serbia. Economic Annals-XXI 169: 4-11. [CrossRef]

Francisco, San, and São Paulo. 2015. About Bloomberg New Energy Finance. pp. 1-2. Available online: http://www.bbhub.io/bnef/sites/ 4/2015/10/BNEF_PR_20151006_Global-Cost-of-Energy.pdf/ (accessed on 8 February 2022).

Focardi, Sergio, and Frank Fabozzi. 2020. Climate Change and Asset Management. The Journal of Portfolio Management 46: 95-107. [CrossRef]

Giramkar, Sudarshan. 2018. Green Banking In India: A Study for Sustainable Devlopment. In Proceedings of Economics and Finance Conferences, no. 6909452. London: International Institute of Social and Economic Sciences.

Hamid, Ishfaq, Md Shabbir Alam, Muntasir Murshed, Pabitra Kumar Jena, Nadia Sha, and Mohammad Noor Alam. 2020. The roles of foreign direct investments, economic growth, and capital investments in decarbonizing the economy of Oman. In Environmental Science and Pollution Research. Heidelberg: Springer. [CrossRef]

Imoughele, Lawrence Ehikioya, and Mohammed Ismaila. 2014. The nature of foreign direct investment and its impact on sustainable economic growth in Nigeria. Journal of Economics and Development Studies 2: 201-32.

Jeklin, Amerd. 2016. Green Finance Report. Satus Report on the Sustainability of Hungarian Financial System. July, pp. 1-23. Available online: https: / / www.mnb.hu/letoltes/20210303-zold-penzugyi-jelentes-angol.pdf (accessed on 6 February 2022).

Khudyakova, Lyudmila S, and Timur R. Urumov. 2021. “Green” Finance in Brics Countries. Mirovaya Ekonomika I Mezhdunarodnye Otnosheniya 65: 79-87. [CrossRef]

Lamperti, Franceseo, Valentina Bosetti, Andrea Roventini, Massimo Tavoni, and Tania Treibich. 2021. Three green financial policies to address climate risks. Journal of Financial Stability 54: 100875. [CrossRef]

Lindenberg, Nannette. 2014. Definition of Green Finance. Bonn: German Development Institute, vol. 3.

Liu, Xiaoyu. 2018. Research on the Development of Inclusive Finance in China. In Proceedings of the 3rd International Conference on Judicial, Administrative and Humanitarian Problems of State Structures and Economic Subjects (JAHP 2018). Advances in Social Science Education and Humanities Research. Paris: Atlantis Press.

Lv, Chengchao, Baocheng Bian, Chien-Chiang Lee, and Zhiwen He. 2021. Regional gap and the trend of green finance development in China. Energy Economics 102: 105476. [CrossRef]

Lyeonov, Serhiy, Tetyana Pimonenko, Yuriy Bilan, Dalia Streimikiene, and Grzegorz Mentel. 2019. Assessment of Green Investments' Impact on Sustainable Development: Linking Gross Domestic Product Per Capita, Greenhouse Gas Emissions and Renewable Energy. Energies 12: 3891. [CrossRef]

Markham, Jerry W. 2022. From the Great Recession to the Covid-19 Pandemic. New York: Routledge. [CrossRef]

MNB. 2019. Green Finance in Hungary. Available online: https://www.mnb.hu/letoltes/green-finance-in-hungary-consultationpaper.pdf (accessed on 2 September 2021).

Monasterolo, Irene. 2020. Climate change and the financial system. Annual Review of Resource Economics 12: 299-320. [CrossRef]

Monnin, Pierre, and Alexander Barkawi. 2015. Monetary Policy and Green Finance: Exploring the Links Council on Economic Policies with Support from in Association with. Available online: https://www.iisd.org/sites/default/files/publications/greeningchinas-financial-system-chapter-7.pdf (accessed on 2 September 2021).

Mumtaz, Muhammad Zubair, and Zachary Alexander Smith. 2019. Green Finance for Sustainable Development in Pakistan. IPRI Journal 19: 1-34. [CrossRef]

Naqvi, Bushra, Nawazish Mirza, Syed Kumail Abbas Rizvi, Małgorzata Porada-Rochoń, and Rania Itani. 2021. Is there a green fund premium? Evidence from twenty seven emerging markets. Global Finance Journal 50: 100656. [CrossRef]

Olmos, Luis, Sophia Ruester, and Siok-Jen Liong. 2012. On the selection of financing instruments to push the development of new technologies: Application to clean energy technologies. Energy Policy 43: 252-66. [CrossRef]

Peng, Mike W., Denis Y. L. Wang, and Yi Jiang. 2008. An institution-based view of international business strategy: A focus on emerging economies. Journal of International Business Studies 39: 920-36. [CrossRef]

Polzin, Friedemann, Mark Sanders, and Alexandra Serebriakova. 2021. Finance in global transition scenarios: Mapping investments by technology into finance needs by source. Energy Economics 99: 105281. [CrossRef]

Pyka, Irena, and Aleksandra Nocon. 2021. Responsible Lending Policy of Green Investments in the Energy Sector in Poland. Energies 14: 7298. [CrossRef]

Ruiz, J. D. González, C. A. Arboleda, and S. Botero. 2016. A Proposal for Green Financing as a Mechanism to Increase Private Participation in Sustainable Water Infrastructure Systems: The Colombian Case. Procedia Engineering 145: 180-87. [CrossRef]

Si, Yanhong, Junfeng Tian, Li Wang, and Xixiu Sun. 2021. Should banks offer concessions? Lending rates for manufacturers' green products. International Journal of Production Research. [CrossRef]

Sutherland, Brando. 2020. Financing a Green New Deal. Joule 4: 1153-55. [CrossRef] 
Taghizadeh-Hesary, Farhad, and Naoyuki Yoshino. 2019. The way to induce private participation in green finance and investment. Finance Research Letters 31: 98-103. [CrossRef]

Tolliver, Clarence, Alexander Ryota Keeley, and Shunsuke Managi. 2020. Policy targets behind green bonds for renewable energy: Do climate commitments matter? In Technological Forecasting and Social Change. London: Elsevier Science Inc., vol. 157. [CrossRef]

Toraman, Cengiz, and Çağatay Başarir. 2014. The Long Run Relationship between Stock Market Capitalization Rate and Interest Rate: Co-integration Approach. Paper presented at the 3rd Cyprus International Conference on Educational Research, CY-ICER 2014, Lefkosa, North Cyprus, 30 January-1 February; vol. 143, pp. 1070-73. [CrossRef]

Witt, Michael, and Arie Lewin. 2007. Outward foreign direct investment as escape response to home country institutional constraints. Journal of International Business Studies 38: 579-94. [CrossRef]

Zenghelis, Dimitri. 2012. A strategy for restoring confidence and economic growth through green investment and innovation. Policy Brief, 18-22.

Ziolo, Magdalena, Filip Fidanoski, Kiril Simeonovski, Vadimir Filipovski, and Katerina Jovanovska. 2017. Sustainable finance role in creating conditions for sustainable economic growth and development. In World Sustainability Series. Cham: Springer, pp. 187-211. [CrossRef] 